\title{
IDENTIFICATION OF MAIN ISSUES AFFECTING THE GROWTH OF GRADUATES' SMALL AND MEDIUM ENTERPRISES (SMES) IN YOGYAKARTA
}

\author{
Hety Budiyanti ${ }^{1}$, Shine Pintor $\mathbf{S}$ Patiro ${ }^{2}$ \\ ${ }^{1}$ State University of Makassar, Economic Faculty, Makassar, Indonesia \\ hetyarzaq@yahoo.com \\ ${ }^{2}$ STMIK AKAKOM, Yogyakarta, Indonesia \\ batikpakuan@rocketmail.com
}

\begin{abstract}
Abstrak
Krisis ekonomi dan kepercayaan yang melanda Indonesia pada tahun 1997 dan 2008 berdampak pada terpuruknya sejumlah usaha di berbagai sektor industri. Namun, hal yang bertolak belakang terjadi pada sektor industri Usaha Kecil dan Menengah (UKM). Sektor UKM mampu bertahan dari krisis dengan menunjukkan pertumbuhan yang signifikan dan mmberikan kontribusi terhadap perekonomian Indonesia. Yogyakarta yang dikenal sebagai kota pelajar mengakui adanya peran penting dari sektor UKM dalam meningkatkan kegiatan perekonomian daerah serta mendorong pemerataan pendapatan masyarakat. Paradigma mengenai penciptaan seorang wirausahawan yang berasal dari lulusan universitas dan perguruan tinggi yang tersebar di Yogyakarta, telah memberikan kontribusi pada peningkatan bisnis milik lulusan di kota tersebut. Tujuan penelitian ini adalah untuk mengungkap mengenai kompetensi yang dimiliki serta dibutuhkan oleh wirausahawan lulusan universitas dan perguruan tinggi yang menjalankan usahanya pada sektor UKM di Yogyakarta. Artikel ini berfokus pada penelitian yang berhubungan dengan kegiatan wirausahawan lulusan universitas dan perguruan tinggi di Yogyakarta dan terutama membahas isu-isu yang berdampak pada pengembangan bisnis mereka. Tujuh isu utama tersebut adalah: pendirian usaha; lokasi; tempat (ukuran, biaya, kepemilikan); perhatian utama; saran dari kolega; pendidikan dan pelatihan; dan dukungan. Sampel dalam penelitian ini merupakan pemilik usaha di Yogyakarta yang tergabung dalam keanggotaan KADIN Departemen Perindustrian cabang Yogyakarta. Sampel lainnya merupakan pemilik usaha di Yogyakarta yang tergabung dalam asosiasi kewirausahaan seperti Konsultan Pengembangan Ide Dan Usaha ARN Yogyakarta. Metode pengumpulan data yang digunakan dalam makalah ini adalah wawancara mendalam dan kuesioner, melalui pendekatan etnografi.
\end{abstract}

Kata kunci: pengusaha, wirausahawan, Usaha Kecil dan Menengah

\begin{abstract}
After the economic crises hit Indonesia in 1997 and 2008 and contributed to downfall of a large number of big businesses in various industries. However, the small and medium enterprises (SMEs) sector has managed to survive from the crisis by showing a significant growth and rising contribution to the economy of Indonesia. Yogyakarta which is known as a city of student has acknowledged the important role of SMEs sector to improve the economic activity of the region and push the income of the people. Rising paradigm at universities and colleges in Yogyakarta about creating entrepreneurship from their graduates has contributed to the rise of graduates' business in this place. The aim of the paper is to take a fresh look into graduate' entrepreneurship on SMEs' scale and competences in Yogyakarta. This paper focuses on a detailed study into the entrepreneurial activities of graduates in Yogyakarta and principally examines issues affecting their business development. Seven main issues were investigated: business establishment; location; premises (size, cost, tenure); concerns; advice utilization; education and training; and support requirements. The sample of the study was assembled from the ministry of department industry and KADIN Yogyakar-
\end{abstract}


ta branch-as formal sources. Other sample sources considered are entrepreneurship associations such as Konsultan Pengembangan Ide dan Usaha ARN of Yogyakarta. Data collecting methods used in this paper are in depth interviews and structured and semi structured questionnaires. Research method will relied mostly on ethnographic techniques

Keywords: entrepreneurs, graduate business, SME’ development

\section{INTRODUCTION}

In recent years, it has become clear that graduates are seriously interested in establishing their own businesses. Since 1997 when the monetary crisis hit Indonesia, self-employment has grown significanly. From approximately 7000 Small and Medium Enterprises in 1980 to 40 million in 2001. At the year 2006, the national bureau statistic (BPS) shown 48,9 million SME absorbed $80 \%$ of work force and contributed to $62 \%$ of GDP (outside oil and gas). Findings from study conducted by Global Entrepreneurship Monitor (GEM) in 2006 indicated that there were $19.6 \%$ of Indonesian citizen (18-64 years) involved in self employment (Business duration are less than 42 months). This record was the second highest in Asia after Philippines $(20.4 \%)$ and above China $(16.2 \%)$ and Singapore (4.9\%). Unfortunately, the BPS record also indicated that 11 Million unemployment was found from 106 million work force in Indonesia. From the data of unemployment in 2008, there were 7.4 million Indonesia citizens at productive age currently unemployed and this number had risen to 7.9 million in 2011. The risen unemployment figure pointed out entrepreneurship had not given appropriate positive contribution to the Economy of Indonesia.

Small and medium enterprises have long been believed to be important in supporting economics development within a country (Mazzarol et al., 1999). One of the important roles of SMEs in this context includes poverty alleviation through job creation. For instance, in the Netherlands, SMEs account $98.8 \%$ of all private sector companies, contribute $31.6 \%$ to Gross Domestic Product (GDP), and employ $55 \%$ of total workforce (EIM Business and Policy Research, 1999, see: Kuratko, 2005). In Italy, SMEs contribute to USD35 million in exports and absorb 2.2 million of national labors (Labrianidis, 2006). According to Indonesian statistics the number of Indonesian SMEs in 2003 was 42.4 millions and they contribute to $56.7 \%$ of GDP, account $19,4 \%$ of total export, and employ 79 millions of work force (BPS and KSME, 2003, see: Indarti et al, 2010). Therefore, in ensuring the economic growth of a country, more attention should be paid into SMEs development.

The whole field of graduate entrepreneurship is a fascinating one, which has been addressed by numerous writers including (Gibb and Ritchie, 1982; Roberts, 1995; Blackburn, 1997; Gibb, 1997; Henry et al., 2005; Wilson, 2006), all of whom appear to identify a growing interest among graduates. Most writers agree that successful businesses are operated by graduates, but this can be affected by the degree to which the graduates adopt the services of a variety of support structures.

There is a wide range of terms used to describe what a graduates' business actually is. They include graduate's start-ups, entrepreneurship, and enterprise. These, however, are largely synonymous and mask the forms within which graduate's businesses operation namely, sole trader, partnership, limited company or occasionally cooperative.

This paper's main aim is to take a fresh look into graduate's entrepreneurship and competencies in Yogyakarta, Indonesia, reflecting a research requirement to identify major issues affecting graduates as they commence and develop entrepreneurial ventures. This study principally examined seven main issues associated with graduates' enterprises as they established, operated, and grew their businesses. These being chosen following a paper from McLarty (2005) and a brainstorming with a pilot group of graduate entrepreneurs. The aspects studied were: 1) Business establishment. This aspect sought to identify the motivating factors and background of the graduates, especially why they opted to commence in business. The literatures are liberal with factors in relation to general business start-up, but the question is whether these factors are similar in respect of graduate entrepreneurs or not. Besides that, whether prior experience was an additional fac- 
tor, was also considered. 2) Location. It was required to examine the impact and relevance of the location decision and to determine how access to customers and suppliers was developed. 3) Premises. Issues such as size, costs and tenure were seen as essential from a research point of view. It was presumed that graduates might have insufficient start-up capital to secure adequate premises. Additionally, it was desirable to investigate the availability of "seedbed premises" for graduate's business use. 4) Issues of concern. Recognizing that there could be a range of issues severely affecting graduate businesses, one of the objectives pursued was to identify the most significant among these. Furthermore, it was essential to remain dispassionate in respect of graduates' concerns since the aim was to encourage spontaneity in responses. 5) Advice utilization. They appeared to be a plethora of advice available in the market place, consequently a study such as this, required to measure quality as well as sources and to consider the medium to longterm impact of advice received. Claims have been made that many business owners"... lie effectively beyond the influence of business advisers" (Clark et al., 2001). 6) Education and training. The focus here required to be on graduate attainments, competencies and skills requirements and to consider any post-graduation training undertaken. Research indicates that considerable attention must be paid to financial management (McMahon, 2001; Henry et al., 2005; Khalid and Larimo, 2012). However, the identification of a wider range of distinct business skills and competencies, which influence success, was regarded as essential although only a tenuous relationship has been seen between training and success (Kuratko, 2005; Labrianidis, 2006). 7) Future support requirements. Ideally and as a result of the research project, it should be possible to make recommendations, based on the findings from each of above categories. These would consider future provisions for the stimulation, development, and encouragement of graduate's enterprise.

\section{THEORETICAL BACKGROUND}

The literature, although growing siginificantly, is relatively sparse in respect of graduate's entrepreneurship. It appeared that this kind of research on graduates' business has never been done in Indonesia. Observing the growing significance of graduate's entrepreneurship in Indonesia, we think it is timely to concentrate on a detailed examination of typical businesses. As observed by Gibb (1996) "there has been an association change in the ethos of academic management education throughout Europe, in particular towards embracing programs and modules on entrepreneurship development, self-employment and indigenous business creation within MBA and higher degree programs" (Garavan and O'Cinneide, 1994; Kale and Singh, 2007). In another review of UK business start-up policy, it has been observed that the educational system is somewhat neglected in respect of making Britain more entrepreneurial (Gavron et al., 1998). The authors argue the need to develop students' commercial skills and business experience. Still others, who have researched the environment surrounding graduate's entrepreneurship (Tackey and Perryman, 1999; Schreiner et al., 2009), perceived that most commentators observe that UK graduates are less entrepreneurially minded than their counterparts in the USA.

Blackburn (1997) compared the relative success of young people in selfemployment in Essex and the north east of England, acknowledging the significant differences Entrepreneurship Among graduates between the two areas. The particular study concentrated on young people in self-employment (18-30 years of age), examining practices and opinions as their businesses developed. The concept of graduate's competencies is also introduced and addressed here since there are lessons for educationalists and graduates.

The term competency originated in work by McClelland (1974), focusing on what people can do to be successful and effective in their roles. He further posited the idea that competencies could be learned and developed. Others who also recognized the importance of competencies include (Boyatzis and Renid, 1989; Labrianidis, 2006; Schreiner et al., 2009) and, more recently, striking a note of caution, (Burns, 1990; Karatko, 2005), who addressed oversimplification in the competency movement. In a study such as this, it appeared legitimate to examine graduate's competencies, since answers here may provide a strong steer for future training provision and graduate's business development. 
Past research showed demographic factors such as gender, age, education and working experience of any individual influenced his willingness to be an entrepreneur (Mazzarol et al., 1999; Khalid and Larimo, 2012).

In general, research conducted by (Indarti et al, 2010) found factors influencing intention of entrepreneurship are different between one country and another. Self-efficacy has proven to influence universities' student intention in Indonesia and Norway. Instrument readiness and working experience were important factors of intention entrepreneurship for students in Norway. Education background was a determining factor of intention for students in Indonesia, only with different direction. This finding was also confirmed by Ahmed et al (2011) that role of personality trait (selfefficacy) influences the entrepreneurial intentions of universities students in Pakistan.

\section{METHOD}

Considering the growing significance of graduate's entrepreneurship to government, policy makers, local advisory organizations and not least to graduates themselves, it is timely to concentrate on a detailed examination of typical businesses. The opportunity arose after the abstract of this paper was accepted for the international conference on entrepreneurship. We chose to carry out a specific study in graduate's businesses at Yogyakarta city which is known as the city of student. The particular study on variables affecting the graduate's businesses in Yogyakarta forms the basis of this paper. Reliance was placed on both quantitative and qualitative interviews comparing a sample of 30 graduate entrepreneurs in Yogyakarta, Indonesia. The sample was assembled following leads from the Chamber of Industry (KADIN) branch Yogyakarta. As was to be expected, some of the businesses identified arose from more that one source. Other sources, such business associations and directories were consulted namely Ikatan Wanita Pengusaha Indonesia (IWAPI) and Komunitas Tangan Diatas (TDA).The TDA community has proven to be the best source of information since most of the sample in our study are member of the community.

All 30 graduates in the sample were written to and advised of the research project. Without exception, all agreed to take part and be interviewed. Given such a sample, it was recognized that the unique external and internal environments might have lacked control. Consequently, the approach included a mix of methods and relied considerably on ethnographic techniques. Such an approach has been ratified by a variety of authors (eg. Hutchinson et al., 2006; North and Smallbone, 2006; Schreiner et al., 2009), who accept that a process of triangulation allows the researcher to focus more wid ly and possibly identify the specific impact of one or another set of actions. As is common in such situations, in-depth interviews were adopted and full notes obtained. This is a wellrecognized approach since it allows the interviewer to probe and elicit detailed answers to questions using non-directive techniques to uncover hidden motivations.

Structured and semi-structured questionnaires were developed to obtain the required information and to influence the direction of investigation. These provided a checklist of core points for discussion. The interviewer adopted a non-directive technique since it was essential to obtain full responses on a series of points, many of which were quite intrusive; such as inquiring into the financial well-being of the firm, profit levels and personal drawings.

\section{ANALYSIS AND RESULTS}

\section{Variable Business Establishment}

In brief, total responts is 30 entrepreneurs. The average of business' age is 2,6 years old with owners' age average 31,5 years old (range from $21-42$ years old). $100 \%$ of the business are sole trader. Background statistics can be found in Table 1.

Table 1: Background statistics

\begin{tabular}{lc}
\hline Categories & Result \\
\hline Mean age of business (years) & 2.6 \\
Meanage of graduates (years) & 31.5 \\
Ages range studied (Years) & $21-42$ \\
Business form: Sole trader & $100 \%$ \\
$\begin{array}{l}\text { Sample size ( number of res- } \\
\text { pondent) }\end{array}$ & 30 \\
\hline
\end{tabular}

Table 2 lists the main start-up motivations among the 30 graduates. The results indicate that these graduates from Yogyakarta 
(66.67\%) decided to be entrepreneur due to their own initiatives. They sought an outlet for their intellectual energies when they determined to launch their businesses. It appeared that "self-employment" in whatever form, promised an engaging impact and held out promise for fuller utilization of their capabilities.

The unemployment record from year 2008-2010 indicates growing number of graduates in Yogyakarta. The growth of graduates has risen higher than the working field available. As a result this situation has driven the graduates to seek other chances for living other than becoming employment. This was supported by evidence that $82 \%$ of the graduates were engaged in unemployment condition before deciding to be an entrepreneur.

Another interesting findings were parental influence appeared to be high (43.33\%) and seeking wealth motivation $(16.67 \%)$ appeared to be low. The high influence from parents indicates the important value dimension of man's relation to other in a family and patriarch orientation of culture (Kroeber et al., 1952; Khalid and Larimo, 2012) which strongly affect Indonesian culture and specifically in Yogyakarta. Surprisingly, creating wealth appeared to be unimportant motivation for these graduates in starting business. These graduates may think that utilization of their capabilities has given a greater reason than wealth in establishing their business. Evidence also confirms that there was little real influence from universities on the entrepreneurial decision $(80 \%$ respondent stated no universities influence on their decision).

The primary influencing factor appeared to be availability of premises, links with customer, proximity to market and links with family. It appears that lower cost is not an important consideration for these graduates despite their constraint in capital availability (Lower cost reason is at fifth position after links with family).

There are some reasons for this; first, graduates chose location with availability of premises as their main consideration in order to maintain close relationship with their customers and proximity to market without considering the cost they must pay to attain such location. We suspect their location decision is due to attainable rent cost in Yogyakarta area. Second, almost $22 \%$ of the respondent chose location and premises already available from their family inheritance. We suspect their choice of location due to links with family reason also impacted by lower cost consideration.

Table 2: (Start up motivations)

\begin{tabular}{lcc}
\hline $\begin{array}{l}\text { What made you start up } \\
\text { your own business? }\end{array}$ & $\begin{array}{c}\text { Number of } \\
\text { responses }\end{array}$ & $\%$ \\
\hline To use my initiative & 20 & 66.67 \\
To shape my own future & 14 & 46.67 \\
To work on my own & 14 & 46,67 \\
Parental influence & 13 & 43.33 \\
To be in charge & 10 & 33.33 \\
To challenge my own & & \\
ability & 9 & 30 \\
Fanily influence & 8 & 26.67 \\
University influence & 6 & 20 \\
To create wealth & 5 & 16.67 \\
Influence of a friend & 5 & 16.67 \\
To work witha friend & 3 & 10 \\
\hline
\end{tabular}

Table 3: (Determinants of location decisions)

\begin{tabular}{lll}
\hline Main reason given & $\begin{array}{l}\text { Mean } \\
\text { score }\end{array}$ & SD \\
\hline Availability of premises & 3.52 & 0.593 \\
Links with customer & 3.5 & 0.518 \\
Proximity to market & 3.409 & 0.5032 \\
Links with family & 3.333 & 0.778 \\
Lower cost & 3 & 0.534 \\
Links with friends & 2.75 & 0.707 \\
\hline
\end{tabular}

The picture shown in Table 3, revealing the main reasons for location decisions emerged. Notable, was the changing nature of premises decisions, from early commencement through development stages. Quite clearly, the graduates began think of opening new branch in different location and premises as time progressed (70\%). They appeared encouraged by their plan to extent market and product development. However, they did not appear to be any significant detriment to business, since many of the firms with "poor" premises had growing sales turnover levels. A significant number of graduates worked from homes (26.7\%) and this option appeared preferable when a speedy start to business was called for and when such work would cause minimum disruption within the home. There was evidence that this arrangement was terminated 
quickly once sales turnover increased to justify investment in premises.

\section{Variable Issues of Concern}

Respondents identified categories of concern with which they had to wrestle, both at commencement and at the business development phase. These concerns were categorized under five headings: marketing, finance, legal, employment and equipment. Four out of five issues were significantly more difficult for graduates to grapple, which are employment; equipment; finance and marketing (see Table 4).

There are $96 \%$ of graduates ranked employment and equipment as their main concern at commencement and only slightly less so (93\%) in the development stage. While $90 \%$ and $86 \%$ ranked finance and marketing respectively as their main concern at commencement and slightly rise to $93 \%$ and $90 \%$ in the development stage. These four categories of concern seemed to have the same important weight for graduates because they appear to be insignificantly different.

The opportunity was taken to break down employment concerns further and these were recorded as follows: salary and bonus $76 \%$, recruitment $73 \%$; skill and competency 66\%; and educational level 43\%. It appeared that the main reason for high concern of employment at the development stage was due to the difficulty in finding highly skilled and competent labor with appropriate salary and bonus. Investing in labor and employment appear to be quite expensive for these graduates. Eight of the graduates confessed that honestly they have issue with their labors. As business grow to development stage, the employment issue decreased a little although still remain highest.

Examining the equipment category of concerns, there were quite the same findings with employment concerns where they declined from early commencement to development stages. At commencement level, the focus of graduates' concern was on production equipment and funding. At development level the focus of graduates' concern has remain the same with lesser concern on funding due to the more fund has flown to the business at this stage and lesser need to add equipment unless they plan to open a new branch.

Table 4: Issues of concern at start-up and development stages

\begin{tabular}{lcccccc}
\hline & Establishment & Mean & SD & Development & Mean & SD \\
\hline Employment & $96 \%$ & 2.93 & 0.94 & $93 \%$ & 3.53 & 0.90 \\
Recruitment & $73 \%$ & 3.27 & 0.55 & $83 \%$ & 3.32 & 0.56 \\
Skill and Competency & $66 \%$ & 3 & 0.73 & $63 \%$ & 3.21 & 0.71 \\
Education & $43 \%$ & 2.85 & 0.69 & $46 \%$ & 2.93 & 0.73 \\
Salary and Bonus & $76 \%$ & 3.26 & 0.45 & $86 \%$ & 3.35 & 0.48 \\
Equipment & $96 \%$ & 2.77 & 1.25 & $93 \%$ & 2.53 & 0.94 \\
Production equipment & $90 \%$ & 3.33 & 0.48 & $80 \%$ & 3.63 & 0.49 \\
Office equipment & $53 \%$ & 3.25 & 0.58 & $56 \%$ & 3.59 & 0.51 \\
Funding & $86 \%$ & 3.23 & 0.51 & $76 \%$ & 3.48 & 0.51 \\
Finance & $90 \%$ & 2.87 & 1.01 & $93 \%$ & 4.1 & 0.84 \\
Accounting & $60 \%$ & 3.5 & 0.51 & $76 \%$ & 3.63 & 0.49 \\
Capital & $53 \%$ & 3.44 & 0.51 & $46 \%$ & 3.57 & 0.51 \\
Cash flow & $86 \%$ & 3.38 & 0.49 & $73 \%$ & 3.41 & 0.50 \\
Audit & $13 \%$ & 3.5 & 0.58 & $13 \%$ & 3.25 & 0.96 \\
No concern & $10 \%$ & 1 & 0 & $6 \%$ & 1 & 0 \\
Marketing & $86 \%$ & 2.7 & 1.06 & $90 \%$ & 3.57 & 0.77 \\
Selling & $46 \%$ & 3.57 & 0.51 & $70 \%$ & 3.67 & 0.48 \\
Customers & $66 \%$ & 3.35 & 0.49 & $76 \%$ & 3.57 & 0.51 \\
Promotion & $86 \%$ & 3.54 & 0.51 & $83 \%$ & 3.38 & 0.49 \\
No concern & $66 \%$ & 3.35 & 0.49 & $76 \%$ & 3.57 & 0.51 \\
Legal & $13 \%$ & 3.7 & 1.06 & $63 \%$ & 3.97 & 0.1 \\
Contract & $13 \%$ & 3.75 & 0.5 & $16 \%$ & 3.6 & 0.55 \\
Permission & $56 \%$ & 3.47 & 0.51 & $63 \%$ & 3.53 & 0.51 \\
\hline
\end{tabular}


Examining the finance category of concerns, there was an interesting finding, namely that graduates' concerns did not decline between the establishment and development stages (defined as year 2 onwards). At commencement, the focus of graduates' concern was on accounting (bookkeeping, VAT, tax, etc.) at $60 \%$. At the development stage, $76 \%$ ranked this highly. The other concerns, identified under the heading of finance, composed - capital, where concerns decline from $53 \%$ to $46 \%$ and cash flow, which also decline from $86 \%$ to $73 \%$. Audit concerns remain the same in importance $(13 \%)$. Only $10 \%$ of the graduates stated that they had no financial concerns at commencement stage and decline to $6 \%$ on development stage. Potential sources of capital may be personal savings, extended family networks, community saving and credit systems, or financial institutions and banks. Korsakiene and Baranauskiene (2011) found that informal sources of credit, though with high interest rates, constitute very substantial contributions to business start-ups in developing countries, where the capital to labour ratio is normally low and small amounts of capital may be sufficient for a business start-up. Marketing category of concerns also increases at the establishment and development stages. The graduates concern was promotion, $86 \%$ at commencement stage and decline to $83 \%$ on development stage.

Other main concern was customer has grown from $66 \%$ to $76 \%$ from commencement to development stage. The other concern was selling. At commencement level, the concern was $46 \%$ and grown significantly to $76 \%$ at development stage. In Indonesia, most SMEs operate along traditional lines in marketing. Higher competition in the market should be responded proactively by SMEs by doing market development. Access to market was a problem faced by SMEs (Hutchinson et al., 2006; Korsakiene and Tvaronaviciene, 2012.). Market development is, therefore, crucial for preserving high growth in the business. North and Smallbone (2006) in their study in UK found that the vast majority of the high growth SMEs had identified and responded to new market opportunities.

Cash flow management in particular, appeared to cause serious difficulty to the graduates. Some entrepreneurs had any significant preparation or training in this task. It suppors tthe empirical evidence, cited in Zucchella et al. (2007) that
“... there is a greater need for careful attention to financial management if the growing concern is to succeed in survival and performance terms". In the majority of $77 \%$, there were no legal concerns at the development stage. Interestingly, this concern shifted to $63 \%$ at development stage. That concers were on composing contract matters and permission from government. Main concern was emphasis on permission from government including TDI (Tanda Daftar Industri), TDP (Tanda Daftar Perdagangan), and HO (Izin Gangguan Usaha) $-56 \%$ at commencement stage and 63\% at development stage.Legal aspect in developing countries in Indonesia is probably of hindrances of success among SMEs. In many cases, dealing with legal aspects has forced the SMEs to allocate significant amount of financial resources due to bribery practices. Legal aspect is often also used in selection operating decision in order to ensure future business success (Mazzarol and Choo, 2003). Unsuitable legislation is also found as obstacle faced by Slovenian SMEs (Duh, 2003). Majority of respondent claimed that the difficulty on arranging permission affair for their business with the government has become an important matters for them, especially at development stage were legitimacy of business is an important matter for the growth of their business.

\section{Variable Advice}

Table 5 revealed kind of advice needed by graduates to develop their business. An observation of advice availability suggests that they need advice in matters of improving business efficiency and empathy in form of assistance and training. Other support needed by graduates from associates or source advisor was recommendation in developing network and relationship with other member of associates.

Table 5: (Advice from business associates and community)

\begin{tabular}{lll}
\hline \multicolumn{1}{c}{ Advice } & \multicolumn{1}{c}{ Mean } & \multicolumn{1}{c}{ SD } \\
\hline Efficiency & 3.818182 & 0.40452 \\
Empathy & 3.666667 & 0.516398 \\
Recommendation & 3.615385 & 0.50637 \\
Relationship & 3.538462 & 0.508391 \\
Knowledge & 3.526316 & 0.512989 \\
Reslt & 3.375 & 0.744024 \\
Analysis & 3.166667 & 0.752773 \\
\hline \multicolumn{2}{r}{ Social networks have an impact on the }
\end{tabular}

Social networks have an impact on the likelihood of successful entrepreneurial endea- 
vor. The study of entrepreneurship has increasingly reflected the general agreement that entrepreneurs and new companies must engage in networks to survive. Networks represent a means for entrepreneurs to reduce risks, transaction costs and to improve access to business ideas, knowledge and capital. A social network consists of a series of formal and informal ties between the central actor and other actors in a circle of acquaintances and represents channels through which the entrepreneurs get access to the necessary resources for business start-up, growth and success (Kristiansen et al., 2003).

In this study, three main source of advice were encountered: Chamber of Industry Yogyakarta Branch (KADIN), Indonesia Business Woman Associates (IWAPI), and Komunitas Tangan di Atas (TDA).Membership data of our respondents were as such; $35 \%$ member of KADIN, $30 \%$ member of IWAPI and $23 \%$ has no membership in any business associates or community. Despite advice received from these sources of advice, seven of our respondent covey that there are parties with certain motives inside such business associates that has no correlation with basic principles of the establishment of business associates.

According to Khalid and Larimo (2012), Small and medium enterprises have certain weakness, which are: 1) Structural aspect, for example weakness in management and organizational area, quality control, technology advancement, capital requirement, labor and employment, also constraint in market access. 2) Cultural aspect in turn will lead to structural weakness. For example, constraint in informational aspect and other requirement in gaining access to capital, marketing, and raw material. Emphasis is needed in building relationship with business environment especially who have bigger bargaining power such as banking industry and government to overcome weaknesses.

Graduates' business in Yogyakarta also faced the same weakness as stated above (Kristiansen et al, 2003). Therefore, advices and assistance is strongly required from their membership in business associates and community in order to advance in their business.

\section{Variable Education and Training.}

In the economy as a whole, the adoption of management training and development pro- grammes has generally been poor (Kuratko, 2005). Similarly, among smaller firms there is evidence of a reluctance to engage in training. However, there is an element of ambiguity among writers about the affects of such. For example, Khalid and Larimo (2012) identified that management training was linked to size and profitability although they did not investigate whether there was a causal relationship between the two or not.Rodrigue $\mathrm{z}$ et al. (2010) identified a weak link between training and business performance. It appeared to be very indifferent responses, from graduate entrepreneurs to the training opportunities in the market place. There were $63 \%$ of them who had received business start-up training extending up to six days; 2 respondents also attended preliminary business ideas workshops; and one person attended entrepreneurship university by STMIK AMIKOM extending up to three months.

The main training requirements related to marketing and finance/accounting. Most graduates were poorly prepared and recorded difficulty in these respects when they first launched their businesses. 37\% of the graduates described marketing as a specific training concern, being inadequately prepared in respect of networking, promotion and selling skills.

Graduate entrepreneurs did not sufficiently relate training and development to the priorities and needs of their organizations. They did not adopt any substantial training courses, rather it appeared that much of the training received was of a "catch-up" nature rather than strategic and developmental. The research extended to the identification of the skills requirements of graduates to run their own businesses and to examine the competencies demanded.

However, it is noted that while there are a growing number of studies published relating to management competencies (Rodriguez et al., 2010; Korsakiene and Baranauskiene, 2011; Korsakiene and Tvaronaviciene, 2012) these often highlight the significance of functional skills such as people management, drives, finance and operations management, etc.

One particular study by Kubč̃ ková (2013) identified lack of confidence among small firms as inhibiting their propensity and even ability to expand. This contrasts with the findings of Korsakiene and Baranauskiene (2011) who highlighted the importance of func- 
tional competencies to success. Martin and Staines (1994) offer three major highlights:

1. Managers stressed the importance of a sound technical understanding of their industry;

2. Many respondents stressed the importance of creativity, risk taking and innovation; and

3. There was near-universal acceptance of people-oriented, personal competencies.

Table 6: Area of training and workshop needed by graduates

\begin{tabular}{lcc}
\hline $\begin{array}{l}\text { Area of training and } \\
\text { workshop required by } \\
\text { graduates }\end{array}$ & $\begin{array}{l}\text { Number of } \\
\text { respondent }\end{array}$ & $\%$ \\
\hline Marketing & 11 & 36.67 \\
Accounting / finance & 10 & 33.33 \\
Production & 6 & 20 \\
Human resources & 4 & 13.33 \\
Information system & 2 & 6.67 \\
Entrepreneurship & 1 & 3.33 \\
$\begin{array}{l}\text { Others (quantum life } \\
\text { transformation) }\end{array}$ & 1 & 3.33 \\
\hline
\end{tabular}

While all of these approaches add to our understanding, they do not focus sufficiently well on the requirements for strategic competency - the ability to develop and apply oneself to long-term business goals. Hence, any application of the competency approach to graduate entrepreneurs needs to introduce this element (McLarty, 1999).

This study progressed to identify relationships with three categories of competency: operational, strategic and personal. Respondents were asked to score factors, again on a Likert scale, which in their experience were associated with successful operation of their business. The results indicate that by a slight margin, the graduate entrepreneurs scored personal competencies as the most essential, with operational competencies following a close second, and strategic competencies lagged someway behind in the third position (see Table 7).

Considering this finding, it appeared that our graduates respondent were highly confident with their personal competencies. Majority of our respondent (18 graduates) admitted they already involved in different business before settling into their business choice now. This fact showed that our respondent were highly competent especially in personal competency in choosing their self-employment way of life.

Our research also examined the benefit of formal education on their business. It appeared that 28 of our respondents admitted the benefit of formal education in setting their way of thinking and mind set as a person in general but apparently not in respect of their business. Majority of our respondent also stated that the knowledge they received from their formal education has no significant usage in operating their business.

As featured in Table 8, in particular, self-confidence, ambition and risk-taking figure in the top third at both start-up and development stages.It appears self confidence is most essential in competency needed to run business by graduates. Second, It appears that strong personal drives (to paraphrase the first preferred competency), are deemed essential to propel the graduates' businesses forward. Third, the ability to sustain a high degree of risk is evident for running business.

Storey (1994) stated entrepreneurship as a mental attitude emphasizing in risk taking, forward looking, self-confidence and independence. This mental attitude will lead an entrepreneur to long term growth in their business. Leadership competency falls into the middle rankings mainly because most of the firms examined had few employees. Hence, there were few opportunities to lead.

Creativity was ranked the last by respondents. Surprisingly, it appears that the graduate entrepreneurs tend to reject creativity competency in developing their own businesses. They did not perceive themselves as being particularly creative when running their businesses either at start-up or growth stages. Although some respondent (12\%) involved in creative industry such as handy craft and apparel goods ranked creativity quite highly but somehow creativity competency is way lagged behind other personal competencies.

In spite of the fact that considerable use had been made of support organizations, evidence was incontrovertible that the graduate entrepreneurs performed poorly in their first year, but thereafter sales and profitability grew considerably. This finding parallels that of most new small businesses (Smallbone et al., 1995). 
Table 7: (Perceived influence of variables affecting competency of graduate's business)

\begin{tabular}{lcccc}
\hline & Mean & SD & Friedman test & Rank \\
\hline Personal & & & & \\
Ability & 3.2 & 0.71 & 5.10 & 8 \\
Creativity & 3.5 & 0.51 & 6.08 & 3 \\
Interaction with environment & 3.47 & 0.51 & 6.02 & 4 \\
Average & 3.39 & & 5.73 & \\
Operational & & & & \\
Education & 3 & 0.83 & 4.48 & 9 \\
Training & 3.2 & 0.81 & 5.17 & 7 \\
Technical knowledge & 3.5 & 0.51 & 6.15 & 2 \\
Experience & 3.53 & 0.51 & 6.30 & 1 \\
Average & 3.31 & & 5.53 & \\
Strategic & & & & \\
Perception & 2.9 & 0.84 & 4.08 & 10 \\
Vision & 3.47 & 0.51 & 5.88 & 5 \\
Planning & 3.43 & 0.51 & 5.73 & 6 \\
Average & 3.27 & & 5.23 & \\
\hline
\end{tabular}

Table 8: (Graduates entrepreneur personal competencies)

\begin{tabular}{lllll}
\hline \multicolumn{1}{c}{ Competency } & Mean & $\begin{array}{c}\text { Friedman } \\
\text { test }\end{array}$ & Rank \\
\hline Self confidence & 3.90 & 4.92 & 1 & \\
Persistency & 3.77 & 4.68 & 2 & \\
Ambition & 3.67 & 4.58 & 3 & \\
Risk taking & 3.57 & 3.417 & 4 & \\
Leadership & 3.27 & 3.73 & 5 & \\
Independency & 3.27 & 3.58 & 6 & \\
Creativity & 2.57 & 2.33 & 7 & \\
\hline
\end{tabular}

Table 9: (Support needed)

\begin{tabular}{lcc}
\multicolumn{2}{c}{ Support requirements } & \\
\cline { 1 - 2 } \multicolumn{1}{c}{ Commencement Stage } & Number of respondent & $\%$ \\
\hline Training & 10 & 33.33 \\
Financing & 19 & 63.33 \\
Others (Moral Support, & 17 & 56.67 \\
$\begin{array}{l}\text { Environment, Friends, Family, Parents Assistance } \\
\text { Development stage }\end{array}$ & & \\
Training & 7 & 23.33 \\
Financing & 14 & 46.67 \\
Others (Government support, Family, Business partners, & 17 & 56.67 \\
Environment, Networking Relation & & \\
\hline
\end{tabular}

\section{Variable Support Requirements}

Table 9 revealed support requirement needed mostly $(63.33 \%)$ by graduate's business in Yogyakarta at the commencement stage was capital support. As their business grew, capital support remain the most important support needed by graduates' business although with slight declined $(46.67 \%)$.This finding supports the findings that to be successful SMEs, the owners of the SMEs should pay more attention to improve marketing strategy, to advance technology, and to get capital access (Indarti et al, 2010).

A more focused approach to training would also appear to be a necessity, particularly with regard to business idea development, market testing, accounting and business planning. This confirms Bevan et al. (1989) statement: “... The process of business planning is best facili- 
tated by people who have the knowledge and competence in the use of planning techniques".

Other support from their environment, friends, family, and business partners appeared to be also highly important $(56.67 \%)$ at both stages. Evidently, this support was recognized by graduates to establish a stronger networking and business relation concerning the growth of their businesses.

\section{CONCLUSIONS}

This study assessed how impacting issues, selfemployment skills and competencies among graduates have developed. With a variable operating environment and considerable political interest in the changing nature of traditional employment, some graduates have successfully focused on the creation of their own jobs. It is not an easy route to follow, since they have to persuade themselves frequently, of the correctness of their business launch decision. Not only so, but also the business idea, financing and marketing implications have to be faced in the cold light of day, when often profits and even cash flow are inadequate to sustain themselves. The study did not seek to justify the business launch decisions, but to evaluate what happened thereafter. The findings are encouraging, although there is considerable diversity in operations, turnover and profitability.

There was significant family support especially from parents, which evidently helped encourage business launch, although little evidence was found of family financial investment. Emphasis on value dimensions of family and patriarch orientation culture in Yogyakarta has proven this evidence.

Most businesses were launched with inadequate funds. Over half of the graduates involved, had prior, although part-time, business experience and stated their main start-up motivation as "to use their own initiative". Most were poorly prepared - it appears that many universities do not generally teach entrepreneurship, although this is changing, nor are courses, which are offered, well designed to develop entrepreneurial drives or skills application. Facts have shown insignificance influence from their universities at start-up business motivation for graduates' respondent.

Location and premises choice were based mostly on premises availability, links with family and customer proximity.Graduates tend to prefer good image to promote the businesses to enhance customer relation and market appeal than cost alone. One of the reasons for this evidence is the low cost of rent in property in Yogyakarta area. Therefore, graduates had little constraints concerning cost in choosing location and premises for their business. Lower cost has not been a strong basis in choosing location, although the highly significant links with family reason also indicate a correlation with cost consideration in choosing location and premises for graduates business in Yogyakarta.

Numerous issues of concern were identified and these had changed over the course of time, but employment, equipment, finance and marketing predominated with most graduates expressing poor ability for addressing such issues in the "real" world. These deficiencies need to be addressed by all support bodies. Variable legal concern is not significant at the commencement stage but experience increasing significance at development stage. It appeared at the beginning of their business, the graduates tend to hinder complicated legal matters with local authority due to high cost in dealing with such matters. As their businesses grow, graduates had taken more seriously legal concern to support their business development.

The assessment of advice given, illustrated the variable nature of advice offered by some support agencies. Business associates and community has proven to be a good source advice for graduates' business. Advice utilization in efficiency and business relation development are most needed by our graduates sample. Unfortunately, universities and colleges do not come out of this study impressively, graduates were not particularly well fitted to operate their own businesses. In spite of the claim that universities prepare students for the workplace, it is questionable whether the teaching of management-oriented modules were sufficiently well applied. Perhaps the trend towards "standalone" modules in entrepreneurship, is the best way forward for supporting graduate's enterprise.

The examination of skills and competencies among the graduates proved beneficial, the decision to classify and group competencies as strategic, operational and personal has given rise to useful findings. The graduates expressed 
personal and operational competency as their main skills category. This had been assumed that the graduates would have had greater faith in their own personal attributes - this is a possible reflection on their perception of education received and their ability and confidence to apply knowledge and learning. It also reflects the fact the most businesses were of fairly recent origin and operational tasks were the most necessary. While the kind of training sought by the graduates were mostly in the area of marketing and finance/accounting where they found to be one of their main concern and lack of ability in developing their business.

Examination of the graduate entrepreneurs' distinct personal competencies proved fruitful. In particular, the ranking of personal competencies was examined. Self-confidence, persistency, ambition, and risk-taking all figured largely in graduates' valuations. The importance of a proper understanding of risk cannot be over emphasized. It is highly unlikely that businesses will be as successful as they could be, if risk is not premeditated and addressed (Smallbone et al., 1995). This research project has revealed new dimensions on the graduates can and do run, successful businesses, albeit with the support of advice services, but as with most new small firms they require time to improve competency and achieve reasonable levels of profitability.

Lastly, it is apparent that further research is required in respect of key business skills, as they apply to graduate entrepreneurs. University and college tutors need to examine the application of their management teaching, particularly since there is evidence of a growing enterprise culture among graduates and it appears, from this study, that they are not academically well served. It is much more difficult and risky for graduates to develop skills "on the job" when they are running their own business, than when employed, hence there is a need for a greater degree of entrepreneurship teaching in an attempt to minimize risk and maximize competencies.

\section{REFERENCE}

Ahmed, I., Aamir, M., \& Ijaz, H. A. 2011. External factors and entrepreneurial career intentions; moderating role of per- sonality traits. International Journal of Academic Research, 3(5).

Bevan, J., Clark, G. and Hakim, C. 1989. A Study of The Flow Into andOut of SelfEmployment. Department of Employment Research Paper, 71, London: Department of Employment.

Blackburn, R. 1997. Enterprise support for young people: a study of young business owners. Paper presented at the 20th ISBA Conference, Belfast, November.

Boyatzis, R. and Renid, A. 1989. The impact of An MBA on managerial abilities, Journal of Management Development, 8, 5, 66-77.

Burns, P. 1990. Strategies for Success and Routes to Failure in Small Business and Entrepreneurship. London. Macmillan.

Clark, D., Berkeley, N. and Steuer, N.2001. Research note' attitudes to growth among owners of small and mediumsized enterprises and the implications for business advice: some evidence from The Clothing Industry in Coventry. International Small Business Journal , 19, 3,72-7.

Duh, M. 2003. Family enterprises as an important factor of the economic development: the case of Slovenia. Journal of Enterprising Culture, 11, 2, 111-130.

Gavron, R., Cowling, M., Holtham, G. and Westall, A. 1998. The Entrepreneural Society, London: IPPR.

Garavan, T. and O'Cinneide, B. 1994. Entrepreneurship education and training programmes. a review and evaluation. Journal of European Industrial Training, 18, 8, 3-12.

Gibb, A. 1996. Entrepreneurship and small business management: can we afford to neglect them in the twenty first century business school? British Journal of Management, 7, 4, 309-21.

Gibb, A. 1997. Small firms' training and competitiveness. building upon the small business as a learning organisation. In- 
ternational Small Business Journal, 15, 3, 13-29.

Gibb, A. and Ritchie, J. 1982. Understanding the process of starting a small business. European (now International) Small Business Journal, 1, 1, 26-45.

Henry C., Hill F., and Leitch C. 2005. Enterpreneurship education and training: can enterpreneurship be taught? Part I. Education-Training, 47,3, 99-107.

Hutchinson, K., Quinn, B., and Alexander, N. 2006. SME retailer internationalization: case study evidence from British retailers. International Marketing Review, 23, 25-53.

Indarti, N., Rostiani, R., \& Nastiti, T.2010. Underlying factors of entrepreneurial intentions among Asian students. The South East Asian Journal of Management, 4(2), 143.

Kale, P., and Singh, H. 2007. Building firm capabilities through learning: the role of alliance learning process in alliance capability and firm level alliance success. Strategic Management Journal, 28, 981-1000.

Khalid, S. and Larimo, J. 2012. Affects of alliance entrepreneurship on common vision, alliance capability and alliance performance. International Business Review, 21, 891-905.

Kristiansen, S., Furuholt, B., and Wahid, F. 2003. Internet cafe entrepreneurs: pioneers in information dissemination in Indonesia.The International Journal of Entrepreneurship and Innovation, 4(4), 251-263.

Korsakiene, R. and Baranauskiene, A.2011. Factors impacting sustainable internationalization: a case of multinational company. Journal of Security and Sustainability Issues 1, 53-62.

Korsakiene, R. and Tvaronaviciene, M. 2012. The internationalization of SMEs: an integrative approach. Journal of Business Economics and Management, 13, 294-307.
Krœber, A. L., \& Kluckhohn, C. 1952. Culture; A critical review of concept and definitions, Papers of the Peabody Museum, vol. XLVII, number 1.

Kubễ ková, L. 2013. Limits of the uppsala model application in the internationalization process of czech SMEs. European International Journal of Science and Technology, 2, 245-254.

Kuratko D. F. 2005. The emergence of entrepreneurship education: development, trends, and challenges. Entrepreneurship Theory and Practice, 29, 483-492.

Labrianidis L. 2006. Fostering entrepreneurship as a means to overcome barriers to development of rural peripheral areas in Europe. European Planning Studies, $14,3-8$.

Martin, G. and Staines, H. 1994. Management competencies in small firms. International Journal of Management Development, 137, 23-34.

Mazzarol, T. and Choo, S. 2003. A study of the factors influencing the operating location decisions of small firms.Property Management, 2, 2, 190-208.

Mazzarol, T., Volery, T., Doss, N., and Thein,V. 1999. Factors influencing small business start-ups.International Journal of Entrepreneurial Behaviour and Research, 5, 2, 48-63.

McClelland, D. 1974. The Achieving Society. New York, NY. The Free Press.

McLarty, R. 1999, The intellectual capital of graduates in relation to SMEs, International Journal of Business Performance Management, Vol. 1 No. 4, pp. 403-16.

McLarty, R. 2005. Entrepreneurship among graduates: towards a measured response. Journal of Management Development, 24, 3, 223-238.

McMahon, R. 2001. Growth performance of manufacturing smes: the influence of financial management characteristics. International Small Business Journal , 19, 3, 10-28. 
North, D. and Smallbone, D. 2006. Developing entrepreneurship and enterprise in europe's peripheral rural areas: some issues facing policymakers. European Planning Studies, 14, 41-60.

Roberts, S. 1995. Youth Employment in Modern Britain.Oxford: Oxford University Press.

Rodriguez, V., Barcos, L., and Álvarez, M. J. 2010. Managing risk and knowledge in the internationalisation process. Intangile Capital, 6, 202-235.

Schreiner, M., Kale, P., and Corsten, D. 2009. What really is alliance management capability and how does it impact on alliance outcome and success? Strategic Management Journal, 30, 13951419.
Smallbone, D., Leig, R., and North, D. 1995. The characteristics and strategies of high growth SMEs.International Journal ofEntrepreneurial Behaviour and Research, 1, 3, 44.

Storey, D. 1994. Understanding the Small Business Sector. London. Routledge.

Tackey, N. and Perryman, S. 1999, Graduates Mean Business, Report 357. Brighton. Institute of Employment Studies.

Wilson, K. 2006. Encouraging the internationalization of SMEs. OECD Papers, 6, 43-66.

Zucchella, A., Palamara, G., and Denicolai, S. 2007. The drivers of early internationalization of the firm. Journal of World Business 42, 268 -280. 